日顎変形誌 Jpn. J. Jaw Deform. 8 (3) : 170 185, December, 1998

\title{
顎矯正手術後の鼻部・上唇部軟組織側貌変化の 予測に関する研究
}

一上顎骨の移動方向別に分類した多变量解析による検討一

$\begin{array}{llllllll}\text { 河 内 } & \text { 満 } & \text { 彦 } & \text { 松 } & \text { 尾 } & \text { 健 } & \text { 菅 } & \text { 原 } \\ \text { 川 準 二 }\end{array}$

\section{Prediction of Soft Tissue Profile in Nose and Upper Lip Region following Orthognathic Surgery \\ -Classified by Directions of Surgical Displacement of Maxilla and Evaluated with Multivariate Analysis-}

\section{Mitsuhiko KAWAUCHI, Kenichi MATSUO, JunJi SUGAWARA, Hitoshi KAWAMURA* and Hideo MiTANi}

\begin{abstract}
The purpose of this study was to investigate the changes of soft tissue profile in the nose and upper lip region following orthognathic surgery.

The subjects were 114 adult females who underwent two-jaw surgery to correct anterior reversed occlusion and were classified into four groups by the directions of surgical displacement of maxilla by cluster analysis. In addition to displacement of hard tissue, some of the soft tissue measurements in the nose and upper lip region such as height and thickness were evaluated with multiple regression analysis.

The results were as follows: (1) Although the tip of the nose was displaced in the upward and forward direction, except in the group where the anterior part of the maxilla was surgically displaced downward, the displacement of the nose as a whole was minimum. (2) The displacement of the upper lip was similar to that of the front part of maxilla, except in the downward group. (3) In addition to the displacement amount of the hard tissue maxilla, thickness and height of the soft tissue in the nose and upper lip region also contributed to significant changes of the profile.

By using a multiple regression analysis, acceptable prediction of the soft tissue profile in the upper lip region would be possible, but precise prediction would be difficult, because of the nose and alar base cinch suture, etc.
\end{abstract}

Key words : Maxillary surgery (上頢骨切り術), Prediction of soft tissue profile（軟組織側貌 予測), Multivariate analysis (多変量解析)

〔Received Jul. 13, 1998〕

東北大学歯学部歯科矯正学講座 (主任: 三谷英夫教授)

*東北大学歯学部第一口腔外科学講座 (主任: 茂木克俊教授)

Department of Orthodontics, School of Dentistry, Tohoku University (Chief : Prof. Hideo MITANI)

* The 1st Department of Oral Surgery, School of Dentistry, Tohoku University (Chief : Prof. Katsutoshi MOTEGI) 


\section{緒 言}

外科的矯正治療は単に咬合の改善を行うだけで なく, 発音や咀嚼などの機能的改善をも目的とし て行われる。また，それに加え術後に良好な顔貌 を獲得することも重要な治療目標となっている。 このため, 初診時や顎矯正手術前にあらかじめ術 後の顔貌を予測することは, 治療計画の立案や患 者へ治療内容を説明する際に重要な事項となって いる。

従来より上下顎硬組織の移動変化に伴う軟組織 の変化については数々の研究報告がなされてい る ${ }^{1-13)}$ 。これらの多くは, 側面頭部 X 線規格写真 を用いて硬組織と軟組織側貌の平均移動率を単回 帰分析によって求めたもので，重回帰分析を用い た研究は少ない。また，近年では視覚的に術後の 顔貌を予測するコンピュータシステムも導入され ているが ${ }^{14-17)}$ ，顎矯正手術後の上顎骨の移動方向 に関しての情報が不明確であるため, 予測の精度 に問題が残されている。

そこで本研究では, 前歯部反対咬合を有する患 者に対し上下顎移動術を施した症例を上顎骨前方 部の移動方向別に分類して, 術後における鼻部・ 上唇部の軟組織側貌の形態変化様相を多変量解析 を用いて詳細に把握することを試みた。

\section{対象および方法}

\section{1. 研究対象}

本研究において使用した対象は東北大学歯学部 附属病院矯正科が管理した反対咬合症例の内, 上 下顎に対し顎矯正手術を適用した成人女性（年齢 15 歳 41 歳, 平均 21 歳） 114 名であり, 以下の 基準に従って選択した。

$1:$ 同一の術者により骨切りが行われた症例で あること。

$2: \mathrm{X}$ 線写真資料は，ブラケットが装着されて いる手術直前とブラケットが撤去されている術後 6 力月以上経過した時点の側面頭部 X 線規格写真 を有すること。また，いずれも撮影時の頭位に不 正が無くRelaxed lip posture で撮影した側面頭 部 X 線規格写真であること。

$3:$ 顔面骨格型に著しい非対称や先天異常が無
い症例であること。

\section{2. 側面頭部 X 線規格写真の分析}

側面頭部 X 線規格写真の透写図上に硬組織 7 点, 軟組織 12 点の計測点を設定し, 頭蓋冠, 前脳頭 蓋底で術前・術後のトレースを重ね合わせた。本 研究では NEC 製コンピューター（PC9801VX） を中心とした測定システムを構築し， $\mathrm{N}$ 点を原点 に $\mathrm{FH}$ 平面に平行および垂直な直線をそれぞれ $\mathrm{X}$ 軸， Y 軸とする座標系を設定した。各計測点をデ ジタイザー（グラフテック製 KD2556 MITABL ET-II）にて順次入力し, 各計測点の座標データ をシステム内のハードディスクに記録した。なお， 20 枚の側面頭部 X 線規格写真を各 3 回トレース し，各計測点をプロットした後，距離計測および 角度計測を行いトレース誤差を算出したところ， 線計測では平均 $0.42 \mathrm{~mm}$ （最大 $0.71 \mathrm{~mm}$, 最小 $0.26 \mathrm{~mm}$ ), 角度計測では, 平均 0.45 度であった。 このことからトレースについては誤差がほとんど 無いものと判断した。

次いで上顎骨前方部の硬組織計測点 (A point, Prosthion，U1）の移動方向を X 軸方向，Y 軸方 向の座標変化量より算出し, ウォード法によるク ラスター分析 ${ }^{18)}$ を行い, 上顎骨の移動方向によっ て 4 群に分類した。その際, 硬組織の移動量が 1 $\mathrm{mm}$ 以上となるパラメーターを採用した。なお， 症例数の少ない群は除外した。

各群ごとに顎矯正手術前後の硬組織, 軟組織計 測点の $\mathrm{X}$ 軸方向, $\mathrm{Y}$ 軸方向の座標変化量を測定シ ステム上から Excel ver 7.0 (Microsoft 社) 上に 移植した。次いで多変量解析プログラム（エスミ 社）を用いて, 次に述べる硬組織計測点の変化量 と術前軟組織側貌における厚さや高さを説明変数 とし, 軟組織計測点の変化量を目的変数としてス テップワイズ法 $(F=2.0)$ により重回帰分析 ${ }^{18)}$ 行い, 術後における軟組織計測点の予測式を導出 した。さらに分散分析により有効性の検定を行っ た。

以下に計測点の解説を記す (Fig. 1)。

(1)硬組織上の計測点

N, S, Po, Or, A point, Prosthion, U1 (2)軟組織側貌上の計測点

Gla：眉弓, Soft N : 鼻根部, NR1 - NR2 • 


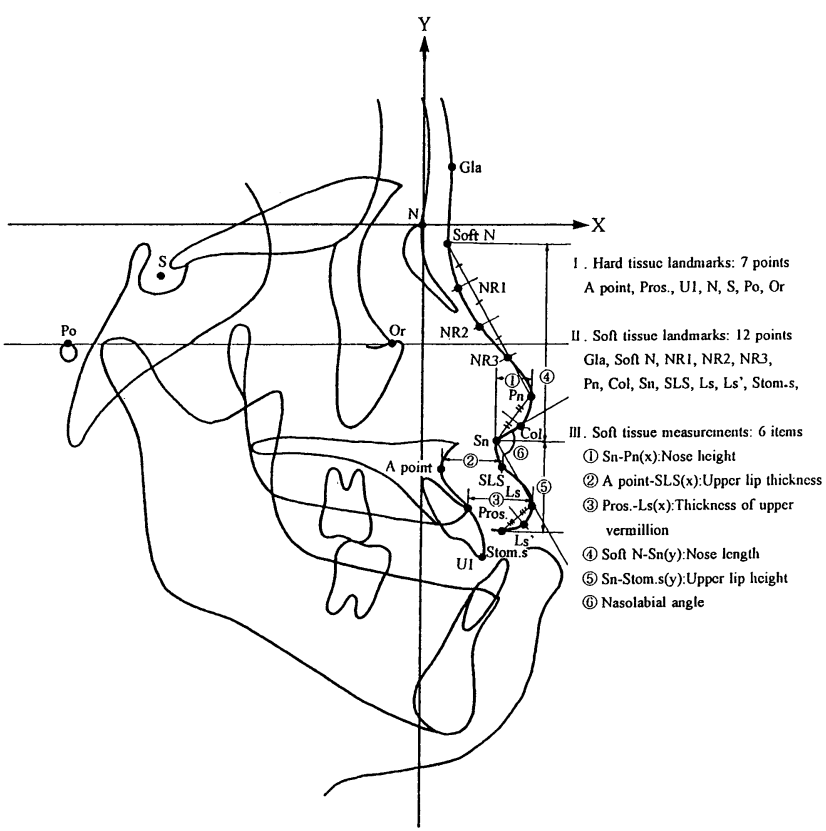

Fig. 1 Reference coordinations, landmarks and soft tissue measurements in this study

NR3：鼻根部から鼻尖点までの鼻梁部を 4 等分し た点, $\mathrm{Pn}$ : 鼻尖点, $\mathrm{Col}$ : 鼻基部と鼻尖部を結ん だ直線の垂直二等分線上の交点， $\mathrm{Sn}$ : 鼻基部, SLS (Superior Labial Sulcus)：上唇の最大湾曲 点, Ls : 上唇最前点, $\mathrm{Ls}$ ' : 上唇最前点と上唇最 下点を結んだ直線の垂直二等分線上の交点,

Stom.s : 上唇最下点

(3)術前軟組織の形態に関係する計測項目 $\mathrm{Sn}-\mathrm{Pn}(\mathrm{x})$ 鼻の水平的高さ, Soft N-Sn $(\mathrm{y})$ : 鼻の垂直的高さ, A point-SLS $(\mathrm{x})$ : 上唇基部の 厚さ, Pros. -Ls $(\mathrm{x})$ : 赤唇部の厚さ, Sn-Stom. $\mathrm{s}$ (y)：上唇の高さ, Nasolabial angle

3. 上顎骨切り術の術式による違いが側貌の変 化に及ぼす影響についての分析

外科的矯正治療において現在行われている上顎 骨切り術はLe Fort I 骨切り術であるが，これ には従来より行われているStandard cut 法と, 中顔面部の審美障害を改善するため骨切り線を上 方の煩骨弓まで延長する High cut 法がある ${ }^{19-20)}$ 。 これらの骨切り術を行った患者群間においては, その骨片形態の違いから術後の正中矢状面におけ
る側貌の変化様相に差異が生じる可能性があるた め, 両群を混合して分析することの是非を確認す ることが必要と考えられた。

そこで両患者群間で軟組織側貌の変化様相に差 異が生ずるか否かを調べるために, 各上顎移動群 において患者をStandard cut施術群と High cut 施術群に分け，側面頭部 X 線規格写真上での上顎 骨硬組織移動量に対する鼻部および上唇部上の軟 組織計測值の変化率を算出し, 両群間に術前後で 有意差が認められるかを $\chi^{2}$ 検定によって判定し た。

その結果, 側面頭部 X 線規格写真上では Gla から Stom. s までの軟組織計測点において両群間 に有意差は認められなかった。

以上のことから上顎骨切り術の術式の違いによ る術後の軟組織側貌の形態変化には差異が無いと いうことが示されたためStandard cut 施術群と High cut 施術群は単一の移動群にまとめて分析 を行うこととした。

4. 上顎骨骨片固定用プレートの除去が軟組織 側貌の変化に及ぼす影響についての分析 


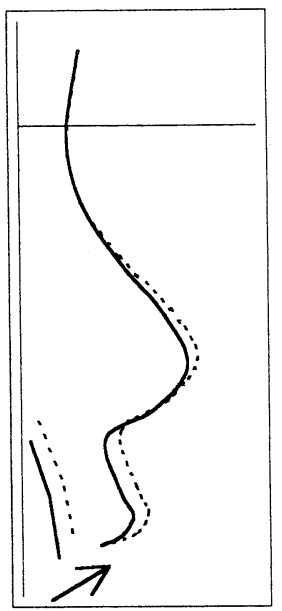

Advancement \& Impaction

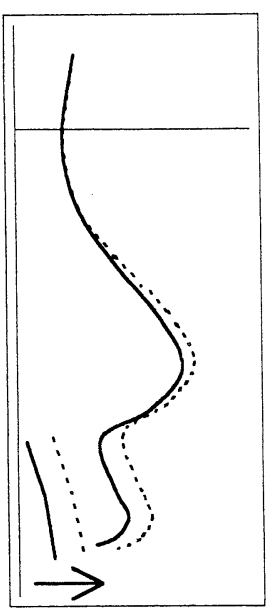

Advancement

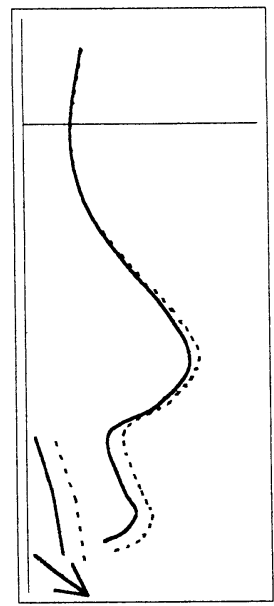

Advancement \& Downgraft

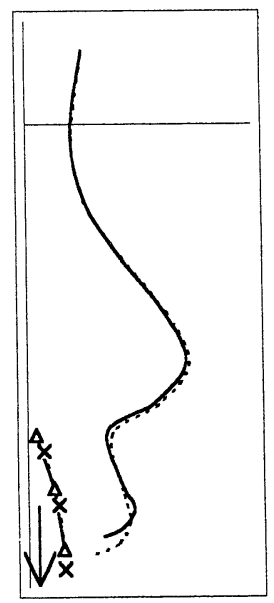

Downgraft

Pre-surgery

Post-surgery

Fig. 2 Scheme of the profile changes classified by the directions of surgical displacement of maxilla

上顎骨切り術において術後における骨の安定性 を高めるためにチタンミニプレートにより上顎骨 片を移動した部位に固定する術式が選択される ${ }^{199}$ 。 このプレートは術後数年で撤去されるが, 厚さ 1 $\mathrm{mm}$ 程度のプレートが皮下から取り除かれること により軟組織側貌に違いを生ずる可能性がある。 このことを検討するために, 上顎移動群 10 名の 側面頭部 X 線規格写真を資料として用い, プレー 卜除去前後の各計測値の差を算出した。

その結果, プレート除去前後の側面頭部 X 線規 格写真のトレースの重ね合わせでは変化がほとん ど認められなかった。

以上の結果から術後のプレート除去は, 軟組織 側貌の計測に影響を及ぼしていないと判断できた。 従って, 術後の側面頭部 X 線規格写真はプレート 埋設の有無により区別せずに分析を行うこととし た。

\section{結 果}

以下に上顎骨前方部の移動方向別に分類した鼻 部・上唇部軟組織の変化様相をまとめた（Fig 2)。
なお, 硬組織の移動方向は U1 で, 鼻部は $\mathrm{Pn}$, 上 唇部は Ls で代表した。

1）上顎前上方移動群 (30 例)

前上方 50.5 度 $(\mathrm{X} ;+2.60 \mathrm{~mm} \mathrm{Y} \mathrm{;} \mathrm{+3.15}$ $\mathrm{mm}$ )

(1)鼻部: 前上方に移動

(X ; $+1.68 \mathrm{~mm}, 64.62 \% \mathrm{Y} ;+1.79 \mathrm{~mm}$, $56.83 \%)$

(2)上唇部 : 前上方に移動

(X ; $2.51 \mathrm{~mm}, 96.54 \% \mathrm{Y} ;+0.60 \mathrm{~mm}, 19.05$ $\%$ )

2) 上顎前方移動群 (20 例)

前方 4.4 度 $(\mathrm{X} ;+4.99 \mathrm{~mm} \mathrm{Y} \mathrm{;}+0.38 \mathrm{~mm}$ )

(1)鼻部 : 前上方に移動

$(\mathrm{X} ;+2.01 \mathrm{~mm}, 40.28 \% \mathrm{Y} ;+1.24 \mathrm{~mm}, \cdots)$

(2)上唇部 : 前方に移動

(X ; + $3.92 \mathrm{~mm}, 78.56 \% \mathrm{Y} ;-0.29 \mathrm{~mm}, \cdots)$

3）上顎前下方移動群 (22 例)

前下方 23.2 度 $(\mathrm{X} ;+3.81 \mathrm{~mm} \mathrm{Y} ;-1.63$ $\mathrm{mm}$ )

(1)鼻部 : 前上方に移動 
$(\mathrm{X} ;+1.66 \mathrm{~mm}, 43.57 \% \mathrm{Y} ;+1.06 \mathrm{~mm}, \quad-$ $65.03 \%)$

(2)上唇部 : 前下方に移動

(X ; $+2.74 \mathrm{~mm}, 71.92 \% \mathrm{Y} ;-0.84 \mathrm{~mm}$, $51.53 \%)$

4）上顎下方移動群 (23 例)

下方 86.9 度 $(\mathrm{X} ;+0.20 \mathrm{~mm} \mathrm{Y}-3.67 \mathrm{~mm}$ )

(1)鼻部 : わずかに前方に移動

(X ; +0.66 mm, ‥ Y ; $-0.26 \mathrm{~mm}, 7.08 \%$ )

(2)上唇部: 後下方に移動

(X ; $-0.77 \mathrm{~mm}, \cdots \mathrm{Y} ;-2.86 \mathrm{~mm}, 77.93 \%$ )

1. 側面頭部 $X$ 線規格写真上での硬組織および 軟組織計測点の重回帰分析

表 1 4（p. 178１85 参照）に各上顎移動群ご との各軟組織計測点の予測式（重回帰式）の偏回 州係数, 重相関係数を算出した結果を示した。上 顎骨前方部の移動が $\mathrm{X}$ 軸, $\mathrm{Y}$ 軸に対し各々平行に 行われた群の移動比率に関しては，それと垂直的 な成分を算出した際に誤差が大きくなるため，こ こでは移動距離についてのみ表示した。

(1) 鼻部の変化と重回帰分析による予測式

鼻部の移動は, NR3, Pn, Col, Sn 点の座標変 化様相で判定した。NR2より上方の計測点は, 移動が少ないためここでは重回帰式を示さないこ とにした。

顎矯正手術前後における鼻部の変化は，上顎骨 前方部の下方移動群以外は鼻尖部が前上方へ移動 していた。下方移動群は，わずかな前方への移動 が認められた。硬組織移動量に対する軟組織の変 化率は垂直方向で差異が認められる群があった。 重回帰分析による予測式のパラメータとして U1 が多く選択された。また, Sn-Pn (x), Soft N-Sn (y) といった術前における鼻部の軟組織計測項目 や, A Point -SLS (x) や Pros. -Ls (x) 等の上 唇部計測項目もパラメータとして認められたが, 硬組織の移動性に関係の無いパラメータが存在す る予測式もあった。概して鼻部における相関係数 は低かった。

（2）上唇部の変化と重回帰分析による予測式

上唇部の変化はSLS, Ls, Ls', Stom.s 点にお ける座標の変化様相で判定した。上顎骨前方部の 前上方移動群では上唇部の前上方への移動, 前方
移動群では前方へ, 前下方移動群では前下方へと 移動し, おおむね移動方向に一致した変化を示し ていた。ただし，下方移動群では後下方への移動 と骨の移動方向とは異なった変化が認められた。 硬組織移動量に対する軟組織の変化率は垂直的に 各郡間で差異が認められた。重回帰分析による予 測式では, 硬組織計測点についてみると U1, 次 いでA pointがパラメータとして多く認められ, 軟組織では Pros. -Ls (x) やA point -SLS (x) と いった上唇部の計測項目だけでなく Nasolabial angle, Sn-Pn（x) といった計測項目もパラメー 夕として認められた。相関係数は, 鼻部よりも高 かった $(\mathrm{r}=0.5 \sim 0.9)$ が, 移動方向や部位による 違いが大きく認められた。一般に垂直成分が水平 成分よりも相関係数の低い傾向を示し，有意性の 無い計測部位も認められた。

\section{考察}

1. 被験者について

本研究は反対咬合を有する上下顎移動術を含む 外科的矯正治療を受けた成人女性を対象として行 われた。これは吉野ら ${ }^{4)}$ と同様, 性差により軟組 織の反応性が異なる可能性が存在することを考慮 したためである。対象は出来るだけ均質なものと するため, 前述したような基準を満たすもののみ を選択した。特にブラケットの有無による軟組織 側貌上の変化が可能性として考えられるため, ブ ラケットが装着されている顎矯正手術直前と手術 後少なくとも 6 カ月以上経過してブラケットが撤 去された側面頭部 X 線規格写真を用いた。

上顎骨切り術の術式が異なることによる顔面形 態の変化を定量的に分析している研究報告は無く, Le Fort I の Standard cutと High cut 間で術 後における軟組織側貌への影響を考慮する必要が あったが, 今回の研究結果では両者を区別して分 析する必要のないことが証明された。このことは， 側貌の正中矢状面上には骨切り術の違いによる影 響が及ばないことを示していると考えられるが， 正中矢状面を離れた中顔面部の軟組織にどの程度 の影響を及ぼしているかに関しては今後解明され るべき課題である。

また，顔面軟組織下に埋設される上顎骨の骨片 
間を固定するチタンミニプレートの存在の有無に より正中矢状面側貌に影響を及ぼす可能性が考え られたが，プレート除去前後では側貌に大きな差 異の存在しないことがわかった。これは厚さ 1 $\mathrm{mm}$ 程度のプレートが軟組織下に存在していたと しても，プレート埋設部および周囲の軟組織の厚 さや張力などの様々な影響を受けるため, 直接的 に軟組織形態の変化に影響を与えにくいものと考 えられた。

2. 上顎骨の移動方向別による症例のグループ 分けについて

外科的矯正治療後の軟組織側貌の変化について は, Radney ら ${ }^{9)}$ Bundgaard ら の報告のように， 上顎骨の移動方向が混在している研究が主である。 本研究では上顎骨の移動方向により術後軟組織側 貌の変化様相に差異が生ずるという仮説に基づき, ウォード法によるクラスター分析を行って客観的 に上顎骨前方部の移動方向を分類し，各群ごとに 術後軟組織側貌の形態変化について分析した。そ の結果, 移動方向別の群ごとに軟組織側貌の変化 様相に違いが認められた。このことは臨床的判断 ではなくクラスター分析を用いることにより客観 的な移動方向の分類が可能となり，均質化された 各移動群における軟組織側貌の変化をより明瞭な ものとして表現できたためであると考えられた。

3. 重回帰分析を用いた顎矯正手術後の軟組織 側貌の予測について

土屋ら ${ }^{21}$ は外科的矯正治療後の軟組織側貌変化 は個体間の変動が大きく, かつ, 上下唇の形態変 化も大きく複雑なため, ある程度の予測は可能で あるが十分な検討が必要であることを指摘してい る。一方, 吉野ら ${ }^{4)}$ は重回帰分析を用いて下顎後 方移動術による下顎骨後方移動量と軟組織の移動 様相の間には高い相関性が認められることを報告 している。上顎骨の移動量に対する軟組織の変化 を予測するために重回帰分析を用いる研究もなさ れているが, Sakimaら ${ }^{11}$ は, 重回帰分析が単回 帰に比べ有効でないとしている。その一方,

Radney ら ${ }^{9)}$ は, 重回帰分析による予測の正確性に ついて報告している。この違いは, 説明変数の設 定により結果が変わることによるものと思われる。 Freihofer ${ }^{5)}$ は, 上唇の水平方向の移動では軟組織
と硬組織の移動比率が各々 $5: 9$ となるが, 薄い 口唇においては $7: 9$ になり, 軟組織厚の違いが 及ぼす反応性の差異について述べている。今回の 研究では, 術後軟組織の変化様相には上顎骨前方 部の硬組織だけでなく, 軟組織の厚さや高さなど が関与していることが判明したが, 得られた相関 係数は必ずしも高いものであるとはいえず，今後 予測精度を向上させるため, 更なる検討が必要で あると思われる。

4. 軟組織側貌各部位の術前後における変化様 相について

(1)鼻部

Bundgaard ら ${ }^{7 /}$ は, 鼻部の変化を予測すること は難しいと報告している。本研究でも一般的に予 測に対する信頼性が低くなっていたが，これは鼻 部軟組織が上顎骨だけでなく術前後で動きの小さ い鼻骨や前頭骨にも付着するため周辺軟組織の可 動性が低く, 上顎骨の移動様相が軟組織の反応性 として反映されにくいことが理由であると思われ る。一方, 鼻尖部付近は鼻骨や鼻軟骨との付着が なくなるため, 上顎骨の移動に対して比較的反応 しやすくなると考えられた。

(2)上唇部

Radney ら`は, 上顎骨が前上方に移動する群で は上唇が上顎前歯切縁の移動量の $50 \%$, 垂直的 に $40 \%$ 反応すると報告したが, 本研究では水平 的に 75-100\%と大きく, 一方, 垂直的には 10-30 \%と小さい割合を示した。上顎前方移動群におけ る硬組織に対する軟組織の反応比率については, Mansour ${ }^{12)}$ は, 水平的には連続的な変化を示す とし, 垂直的な変化を予測することは難しいが上 方に移動すると述べている。本研究では, Dann ${ }^{6)}$ らが報告した割合である水平的に $50 \%$ よりやや 大きく $75 \%$ を示したが, Carlotti ら ${ }^{8)}$ の報告 $(80-$ $90 \%$ ）よりはやや小さい值であった。上唇部の 移動は上顎骨の移動方向とほぼ一致していたが, 下方移動群では上唇部は前方ではなく逆に後方へ 移動していた。これはOver closureの傾向にあっ た下唇によって圧平されていた上唇が, 上顎骨の 下方移動に伴って伸展され, それによって上唇が 薄くなった結果, 上唇部計測点が後退したためと 考えられる。また, 一般にU1 to Stomion が過 
少で上顎前歯切縁の上唇最下点に対する露出度が 不足していたり，逆にVertical Maxillary Excess などで上顎前歯の露出度が多過ぎ Gummy smile を示すような症例では，上顎骨前方部を上 下的な成分を含む方向に移動させて U1 to Stomionの改善を図る必要がある。この際，上顎 骨前方部の移動に伴い上唇最下点も同様な上下的 成分を持つ方向に移動することが，本研究の結果 より明らかになった。このことから，望ましい両 者の関係を獲得するためには, 軟組織の移動分を 加味して上顎骨の移動量を多めに設定する必要が あるものと考えられた。一方，上唇部計測点にお ける相関係数は 0.5-0.9 と鼻部に比べれば高い值 を示してはいるものの，下顎骨後方移動術におけ る下顎骨に対する下唇やオトガイ部の相関性より も低い值であり，上唇部の術後軟組織側貌を予測 することは容易ではないと考えられた。上唇部は 前述した鼻部と連続しているために鼻部の比較的 小さな移動の影響を受け，上顎骨の移動が直接反 映されにくく, Lines ${ }^{10)} ら か ゙$ 述べるような下顎骨と 同様の反応を示さないためと考えられる。また， Carlotti ら ${ }^{8)}$ が述べるように，上顎骨の手術時に 行われるAlar base cinch sutureにより硬軟両 組織の移動比率の予測精度が低いものとなってい る点も重要であると考えられる。すなわち，これ により鼻翼部の幅径を維持するため鼻基底部軟組 織が上顎骨の移動方向に関係なく前方に押し出さ れしまい, その量をコントロールすることが難し いためである。また，上顎骨の前方移動術の際に 前鼻棘が張り出さないように行われる Reduction of ANSの影響が大きいことも軟組織側貌の予測 精度を低くしている原因の一つとして考えられる。

\section{結 論}

上下顎移動術を適用した成人女性をクラスター 分析を用いて上顎骨前方部の移動方向別に分類し, 鼻部や上唇部について上顎骨の硬組織だけでなく 軟組織の厚さや高さを説明变数として重回帰分析 を行った。

1. 鼻部の偏位は小さかったが, 鼻尖部は上顎 骨前方部が下方に移動する群以外は, 前上方へ移 動していた。
2. 上唇部は上顎骨前方部が下方に移動する群 以外は, 移動方向に一致した軟組織の偏位を示し た。また, 軟組織の偏位に関しては硬組織の変位 量に加え軟組織の厚さや高さが関与していること が明らかになった。しかし，上唇部の変化につい ては鼻部や Alar base cinch suture 等の影響も あり重回帰式を用いたとしても正確な予測は困難 であることが示された。

本研究の一部は, 第 5 回顎変形症学会（平成 7 年, 浜 松市）ならびに第 6 回顎変形症学会（平成 8 年，仙台市） に拈いて発表した。

\section{参考文献}

1) Hershey, H. G., et al.: Soft-tissue profile change associated with surgical correction of the prognathic mandible, Am J Orthod 65: 483-502, 1974.

2）土屋雅文，他：骨格性下顎前突症に対する外科的矯 正治療前後の軟組織側貌変化について一手術前後の 変化を中心として一， 日矯歯誌，42:168-177, 1983.

3）吉田憲司：下顎前突症患者術後の予想顔貌に関する 研究, 日口外誌, $34: 1237-1254,1988$.

4）吉野清吉, 他：下顎前突者における下顎枝矢状分割 術後の軟組織側貌の予測とその説明変数の検討, 日 顎変形誌, $5:$ 16-30, 1995.

5) Freihofer, H. P. M.: The lip profile after correction of retromaxillism in cleft and non-cleft patients, J. Maxillofac Surg 4: 136-141, 1976.

6) Dann, J. J., et al. : Soft tissue changes associated with total maxillary advancement: a preliminary study, J Oral Surg $34: 19-23$, 1976.

7) Bundgaard, M., et al. : Changes during and following total maxillary osteotomy (Le Fort I procedure): a cephalometric study, Euro J Orthod 8: 21-29, 1986.

8) Carlotti, A. E., et al.: Facial Changes Associated with Surgical Advancement of the Lip and Maxilla, J Oral Maxillofac Surg 44 : 593-596, 1986.

9) Radney, L. J., et al.: Soft-tissue changes associated with surgical total maxillary intrusion, Am J Orthod 80 : 191-212, 1981.

10) Lines, P. A., et al. : Soft-tissue changes in relationship to movement of hard structures in orthognathic surgery: A preliminary report, J Oral Surg 32:891-896, 1974.

11) Sakima, T., et al.: Soft tissue response to Le Fort I maxillary impaction surgery, Int 
J Adult Orthod and Orthog Surg 4 : 221-231, 1987.

12) Mansour, S., et al. : An evaluation of softtissue changes resulting from Le Fort I maxillary surgery, Am J Orthod 84 : 37-47, 1983.

13) Schendel, S. A., et al. : Superior repositioning of the maxilla: Stability and soft tissue osseous relations, Am J Orthod 70 : 663-674, 1976.

14）高橋一朗, 他 : ビデオ画像を用いた術後顔貌予測シ ステムの予測信頼性について, 日顎変形誌, $1: 128$ 133, 1991.

15) Sarver, D. M.: Video imaging-a computer facilitated approach to communication and planning in orthognathic surgery, British $\mathrm{J}$ Orthod $20: 187-191,1993$.

16) Sameshima, G. T., et al. : Predicting soft tissue changes in maxillary impaction surgery:a comparison of two video imaging systems, Angle Orthod 67 : 347-354, 1997.

17) Upton, P. M., et al.: Evaluation of video imaging prediction in combined maxillary and mandibular orthognathic surgery, Am J Orthod Dentfac Orthop 112 : 656-665, 1997.

18）奥野忠一, 他 : 多変量解析法, 改訂版, 日科技連出 版社, 東京, 1981，25-157，391-411 頁.

19) Abubaker, A. O., et al. : Modified Le Fort I (Maxillary-Zygomatic) Osteotomy: Rationale,Basis, and Surgical Technique, J Oral Maxillofac Surg 49 : 1089-1097, 1991.

20) Bell, W. H., et al. : Art and science of the Le Fort I downfracture, Int J Adult Orthod and Orthog Surg $3: 23-52,1988$. 


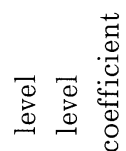

ㅇํ ㅇํㄱ

幽㱏

๙

$\vec{\sigma} \vec{\sigma}$

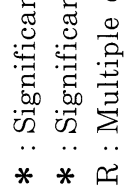

?ำ

\begin{tabular}{|c|c|c|c|c|c|c|c|c|}
\hline 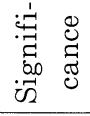 & & $\begin{array}{l}* \\
*\end{array}$ & & $*$ & $\begin{array}{l}* \\
*\end{array}$ & * & $\begin{array}{l}* \\
*\end{array}$ & $\begin{array}{l}* \\
*\end{array}$ \\
\hline 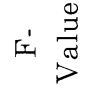 & 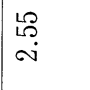 & $\begin{array}{l}\text { g } \\
\infty \\
\infty\end{array}$ & 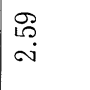 & $\begin{array}{l}\infty \\
\infty \\
\dot{\infty}\end{array}$ & $\begin{array}{l}\infty \\
\infty \\
\infty\end{array}$ & $\begin{array}{l}\infty \\
0 \\
\text { ลे }\end{array}$ & 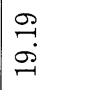 & $\begin{array}{l}8 \\
0 \\
0\end{array}$ \\
\hline $\mathscr{\mu}$ & : & छ) & : & $\begin{array}{l}0 \\
0 \\
0 \\
0\end{array}$ & ঙ্ণি & 웅 & 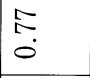 & $\begin{array}{l}18 \\
0 \\
0\end{array}$ \\
\hline 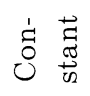 & $\begin{array}{l}\text { iै } \\
\text { เి } \\
\text { i }\end{array}$ & $\stackrel{\sim}{\mathcal{+}}$ & 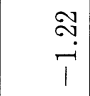 & $\underset{\infty}{\stackrel{\sim}{\infty}}$ & $\stackrel{\varrho}{2}$ & $\stackrel{م}{\circ}$ & $\stackrel{\check{N}}{+}$ & $\stackrel{\infty}{+\infty}$ \\
\hline
\end{tabular}

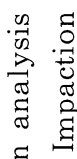

章

क्ष

壱

을

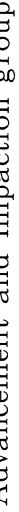

峲密

I

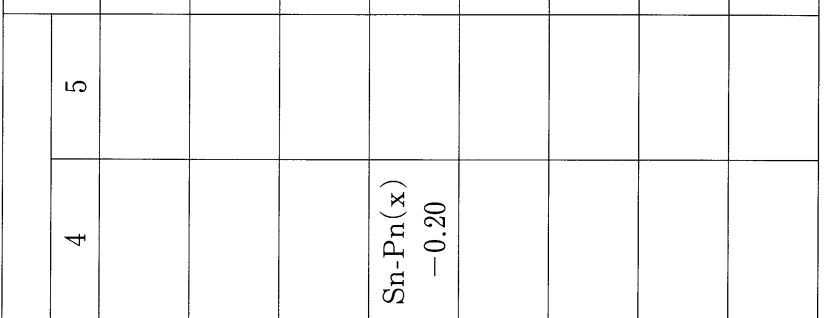

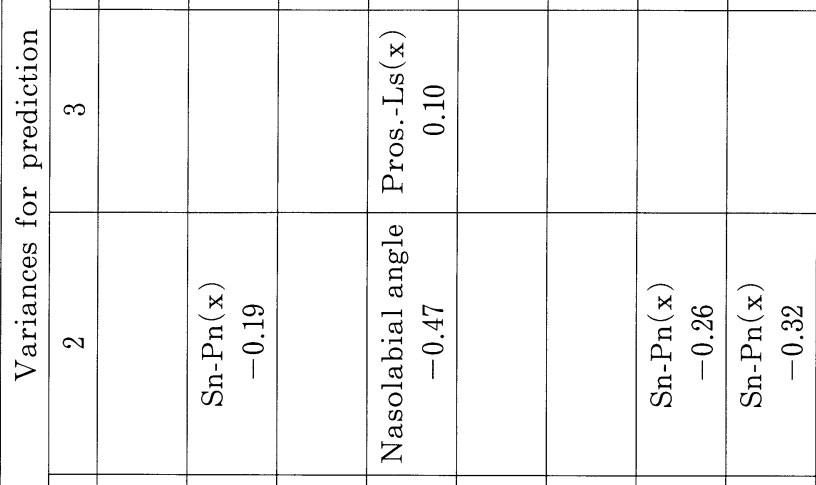

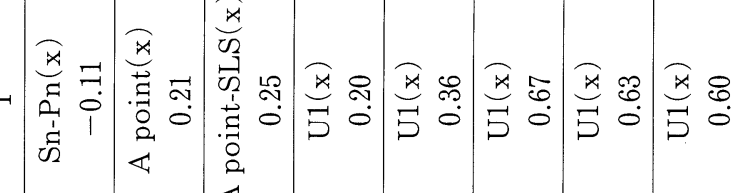

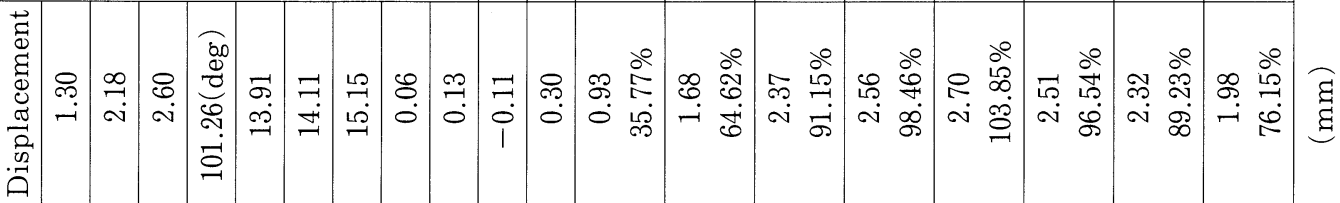

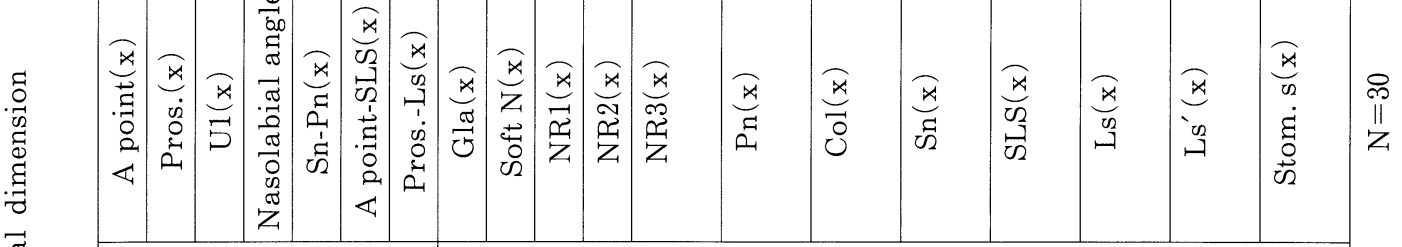




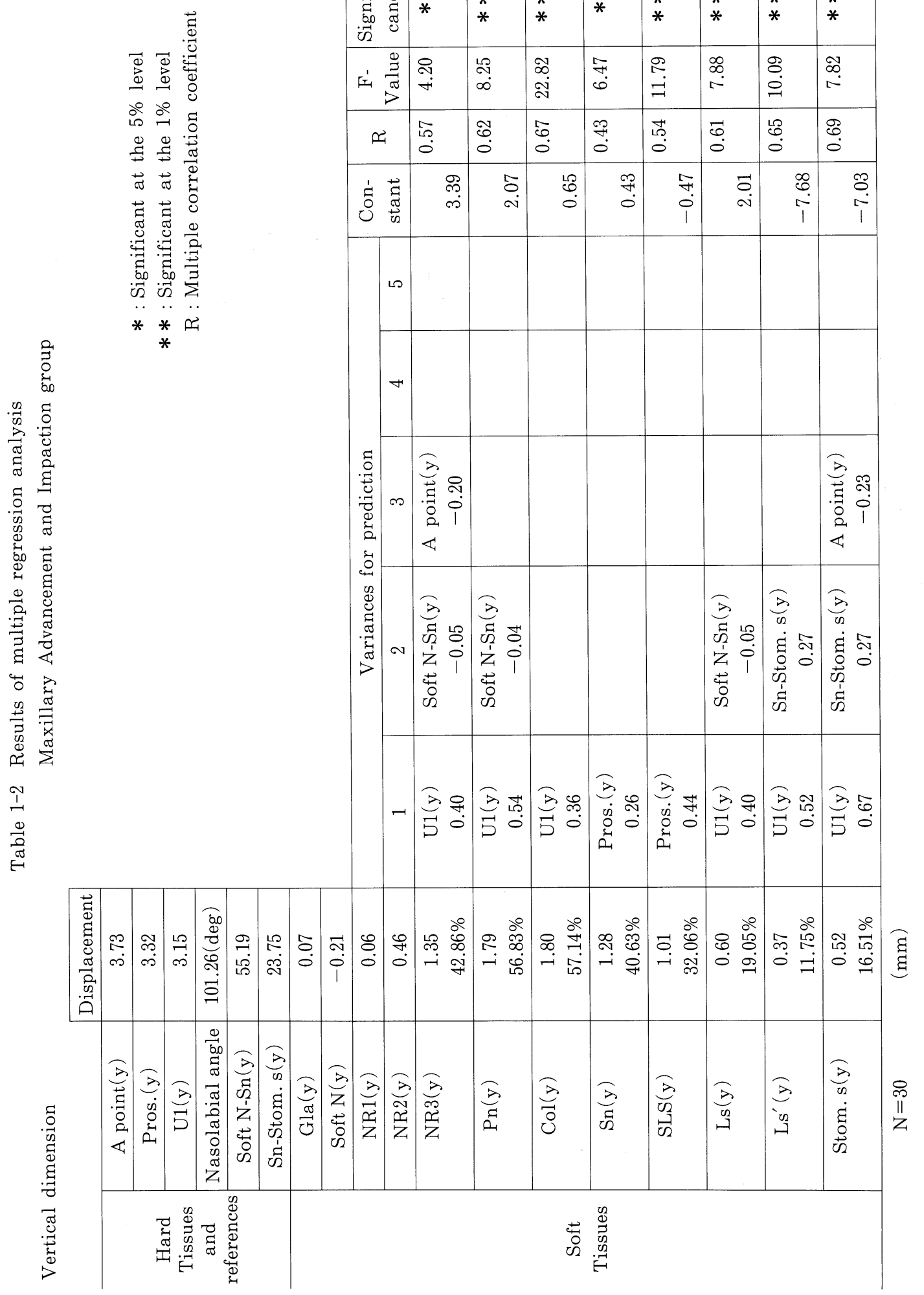




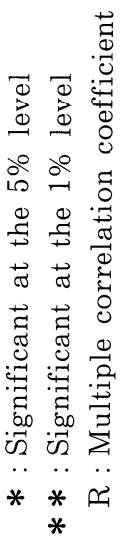

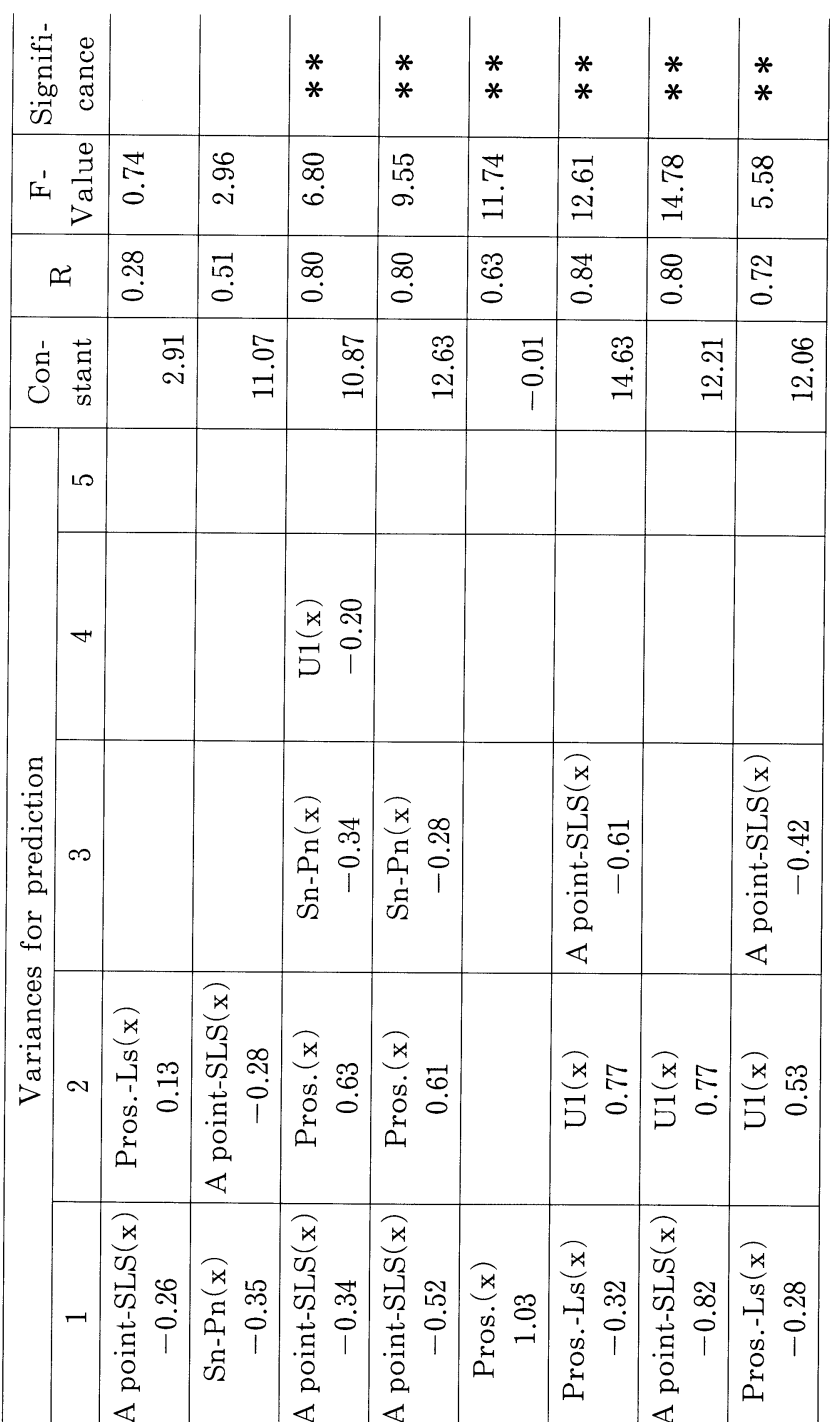

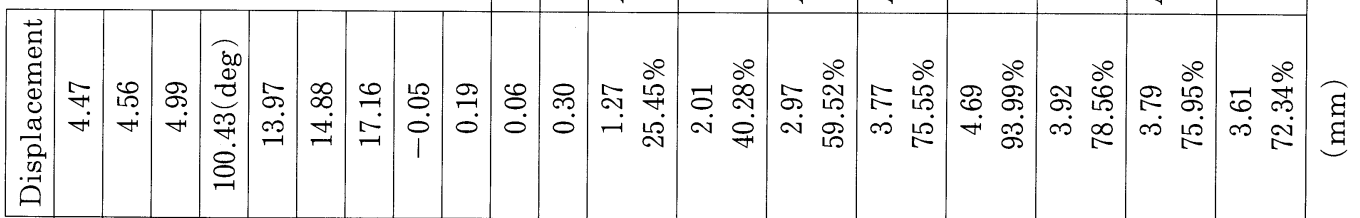

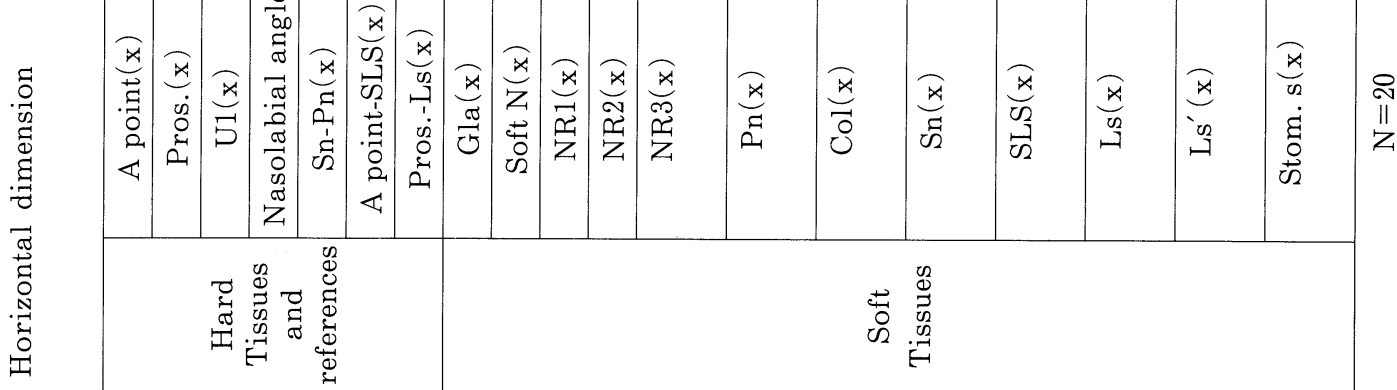




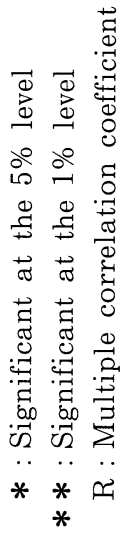

\begin{tabular}{|c|c|c|c|c|c|c|c|c|c|}
\hline & & $\begin{array}{l}* \\
*\end{array}$ & * & $*$ & * & * & & & $\begin{array}{l}* \\
*\end{array}$ \\
\hline & & $\begin{array}{l}\mathcal{7} \\
\cdots \\
0\end{array}$ & $\underset{\sim}{\stackrel{H}{+}}$ & $\begin{array}{l}\text { ণิ } \\
\text { is }\end{array}$ & \begin{tabular}{l}
$\infty$ \\
\hdashline \\
+ \\
\end{tabular} & $\underset{+}{\stackrel{\leftrightarrow}{+}}$ & I & . & \begin{tabular}{l}
$\infty$ \\
\hdashline \\
\end{tabular} \\
\hline A & & $\begin{array}{l}1 \\
\qquad 8 \\
0 \\
0\end{array}$ & 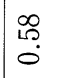 & $\begin{array}{l}\mathscr{O} \\
\stackrel{0}{0}\end{array}$ & $\begin{array}{l}8 \\
0\end{array}$ & 苞. & 占 & $\begin{array}{l}\infty \\
\stackrel{\infty}{\infty} \\
0\end{array}$ & $\begin{array}{l}\infty \\
\infty \\
0\end{array}$ \\
\hline$\dot{\prime \prime}$ & & $\begin{array}{l}\text { के } \\
\text { ì } \\
i\end{array}$ & $\begin{array}{l}\stackrel{\vec{N}}{\infty} \\
\infty\end{array}$ & $\begin{array}{l}\stackrel{9}{4} \\
\text { i. } \\
i\end{array}$ & ip & $\begin{array}{l}\stackrel{+}{+} \\
\stackrel{+}{1}\end{array}$ & $\begin{array}{l}\infty \\
\infty \\
i\end{array}$ & $\stackrel{\substack{20 \\
i}}{i}$ & $\begin{array}{l}\vec{b} \\
\stackrel{0}{1} \\
i\end{array}$ \\
\hline & مـا & & & & & & & & $\begin{array}{ll}\widehat{B} & \infty \\
\Xi & 0 \\
5 & 0\end{array}$ \\
\hline & $r$ & & & & & & 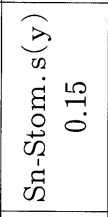 & 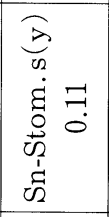 & 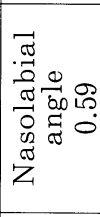 \\
\hline & $\infty$ & & & & & & 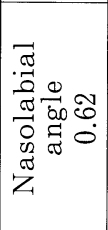 & 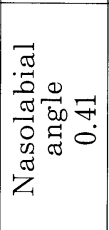 & 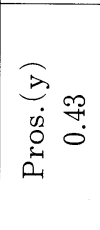 \\
\hline & $\sim$ & 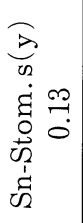 & 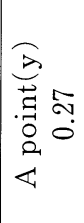 & 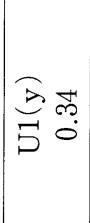 & 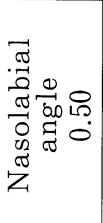 & 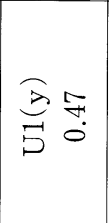 & 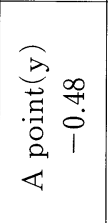 & 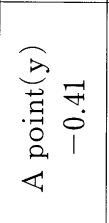 & 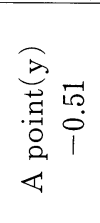 \\
\hline & -1 & $\begin{array}{ll}\vec{B} & \\
\dot{w} & \vec{L} \\
0 & 0 \\
\dot{D} & 0\end{array}$ & 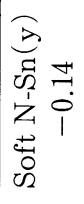 & 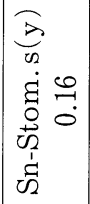 & $\begin{array}{c}\widehat{3} \\
\overrightarrow{5} \\
\overrightarrow{5}\end{array}$ & 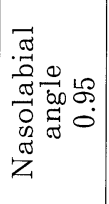 & $\begin{array}{l}\widehat{B} \\
\stackrel{5}{5} \\
\vec{b}\end{array}$ & $\begin{array}{ll}\widehat{B} & 1 \\
0 & 0 \\
& 0 \\
& 0\end{array}$ & 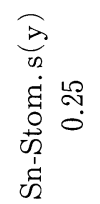 \\
\hline
\end{tabular}

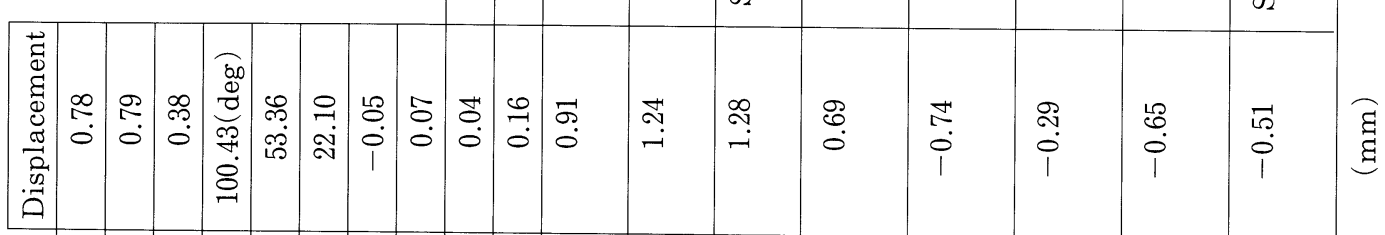

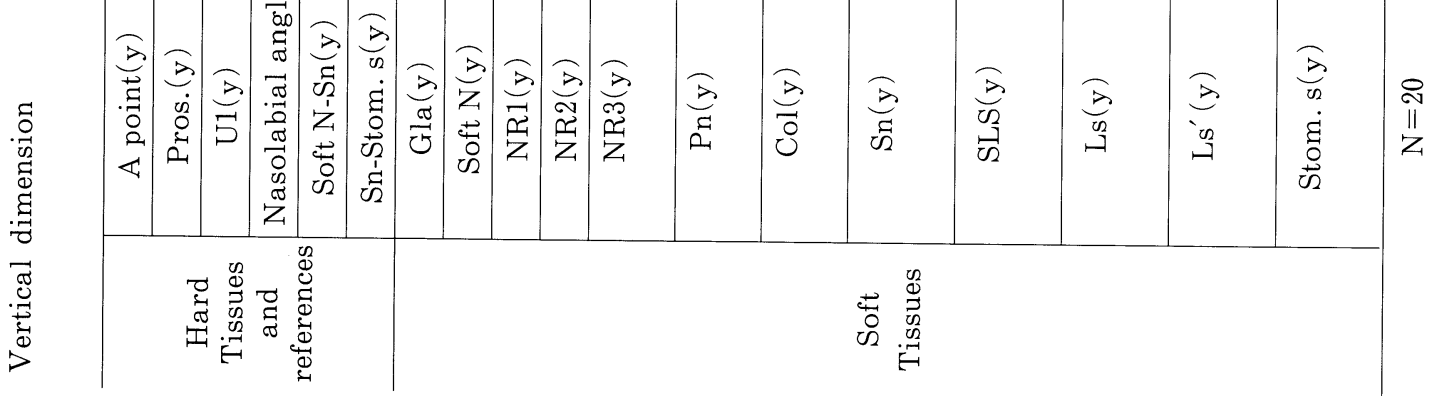




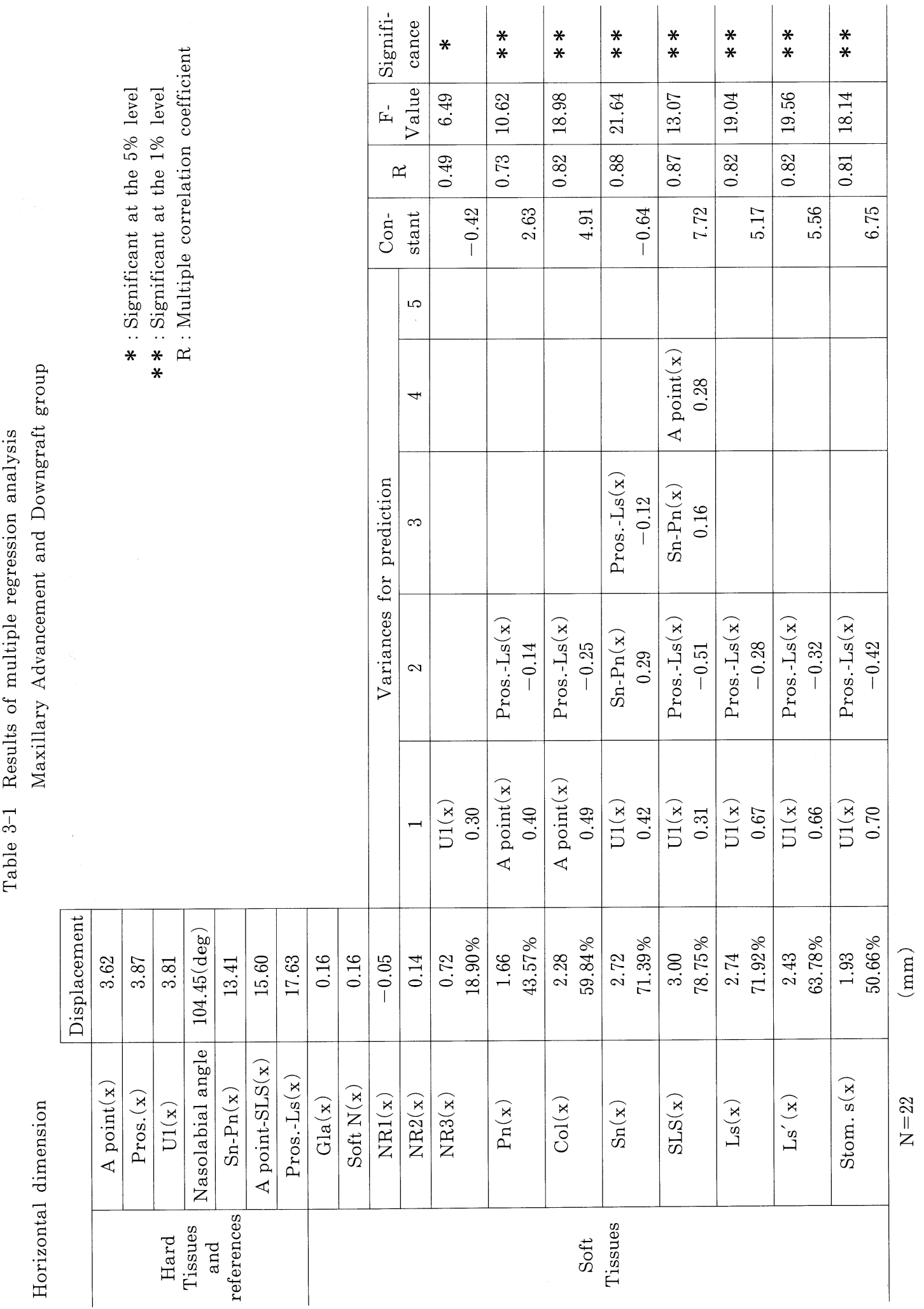




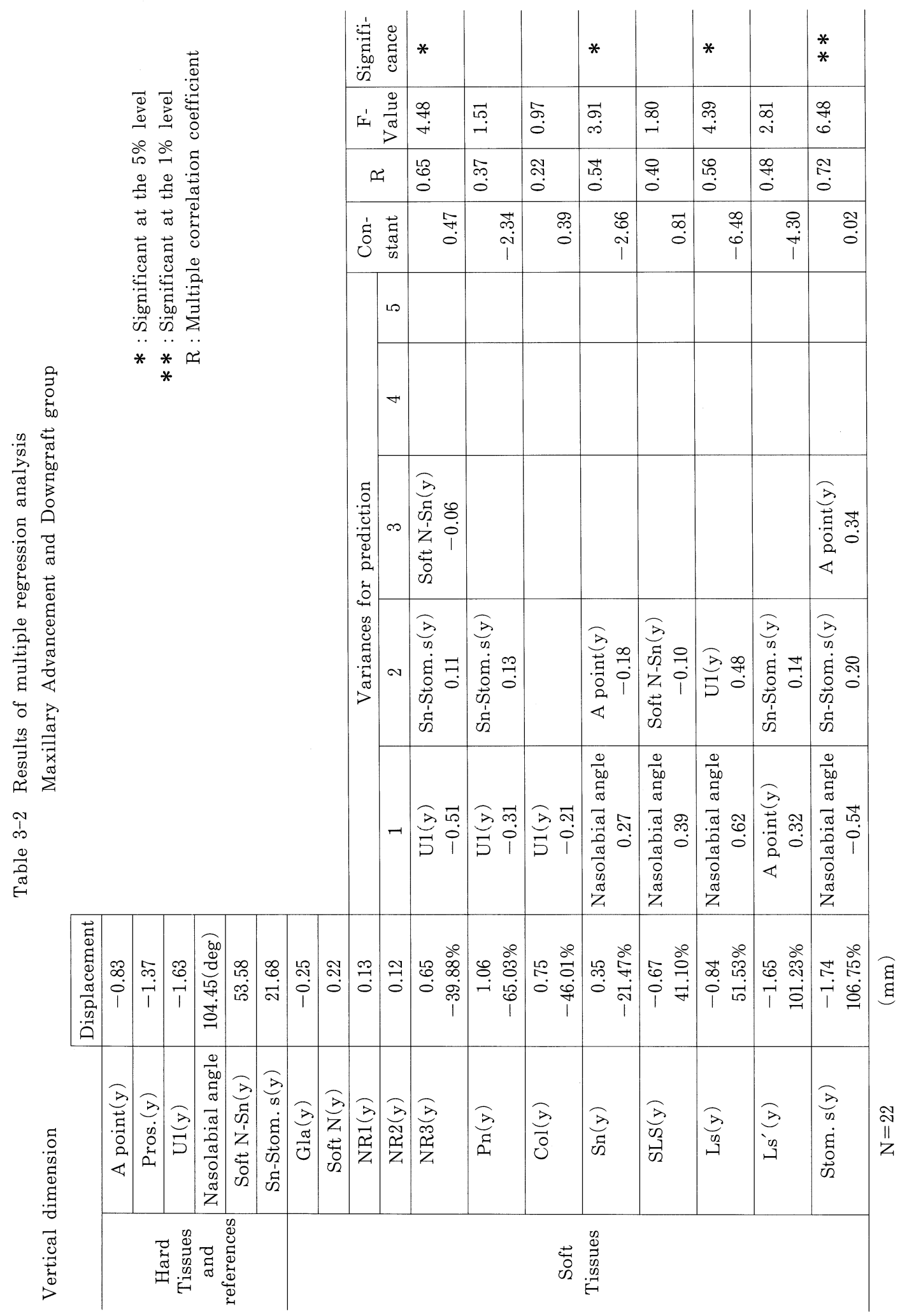




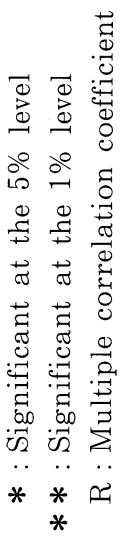

\begin{tabular}{|c|c|c|c|c|c|c|c|c|c|}
\hline & & $\begin{array}{l}* \\
*\end{array}$ & $\begin{array}{l}* \\
*\end{array}$ & $\begin{array}{l}* \\
*\end{array}$ & $\begin{array}{l}* \\
*\end{array}$ & $\begin{array}{l}* \\
*\end{array}$ & $\begin{array}{l}* \\
*\end{array}$ & $\begin{array}{l}* \\
*\end{array}$ & $\begin{array}{l}* \\
*\end{array}$ \\
\hline & & $\begin{array}{l}\infty \\
\stackrel{\infty}{\sigma}\end{array}$ & $\begin{array}{l}\infty \\
\infty \\
\oplus \\
0\end{array}$ & $\begin{array}{l}18 \\
\$ \\
\infty \\
\end{array}$ & \begin{tabular}{|l|}
\multirow{O}{*}{} \\
ปे \\
\end{tabular} & $\begin{array}{l}\ddot{b} \\
\dot{0} \\
\stackrel{D}{-}\end{array}$ & $\begin{array}{l}\tilde{N} \\
\text { L̊ } \\
\text { L } \\
\end{array}$ & $\begin{array}{l}\text { 움 } \\
\text { 염 } \\
\end{array}$ & $\begin{array}{l}\infty \\
\stackrel{\infty}{0} \\
\stackrel{0}{0} \\
\end{array}$ \\
\hline$\rho$ & & 它 & $\begin{array}{l}0 \\
0 \\
0\end{array}$ & 둥 & $\begin{array}{l}\infty \\
\infty \\
0\end{array}$ & $\stackrel{\infty}{\infty}$ & $\begin{array}{c}\infty \\
\infty \\
0\end{array}$ & $\begin{array}{c}\infty \\
\infty \\
0 \\
0\end{array}$ & $\begin{array}{l}0 \\
0 \\
0\end{array}$ \\
\hline ¿े & & $\begin{array}{l}\stackrel{0}{0} \\
\overrightarrow{0} \\
1\end{array}$ & \begin{tabular}{l}
5 \\
\multirow{0}{*}{} \\
$i$ \\
1
\end{tabular} & $\stackrel{+}{\stackrel{ \pm}{i}}$ & 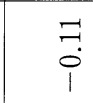 & $\begin{array}{l}\vec{\infty} \\
0 \\
0\end{array}$ & 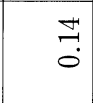 & $\begin{array}{l}\sigma \\
\sigma \\
i \\
i\end{array}$ & $\begin{array}{l}\ddot{10} \\
0 \\
\dot{\varphi}\end{array}$ \\
\hline & مـ & & & & & & & & \\
\hline & 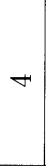 & & & & & & 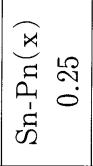 & 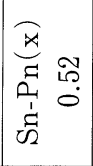 & \\
\hline 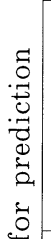 & $\infty$ & & & 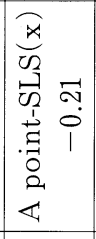 & & & 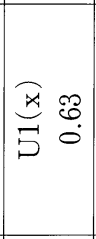 & 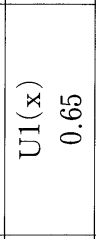 & 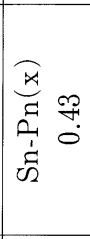 \\
\hline - & $\sim$ & 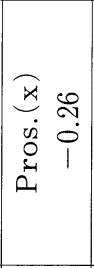 & 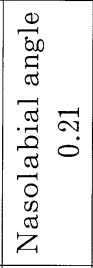 & 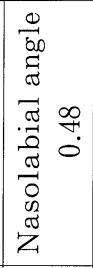 & 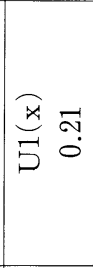 & 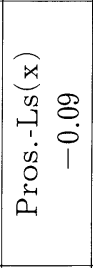 & 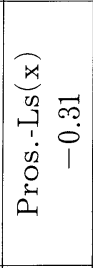 & 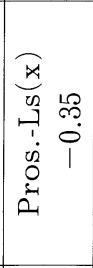 & 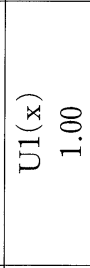 \\
\hline & $\neg$ & 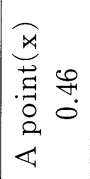 & 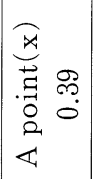 & 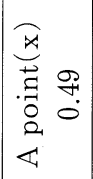 & 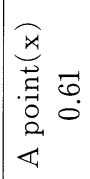 & 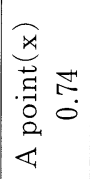 & 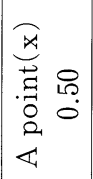 & 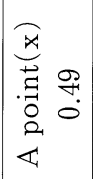 & 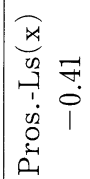 \\
\hline
\end{tabular}

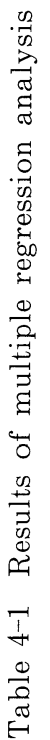

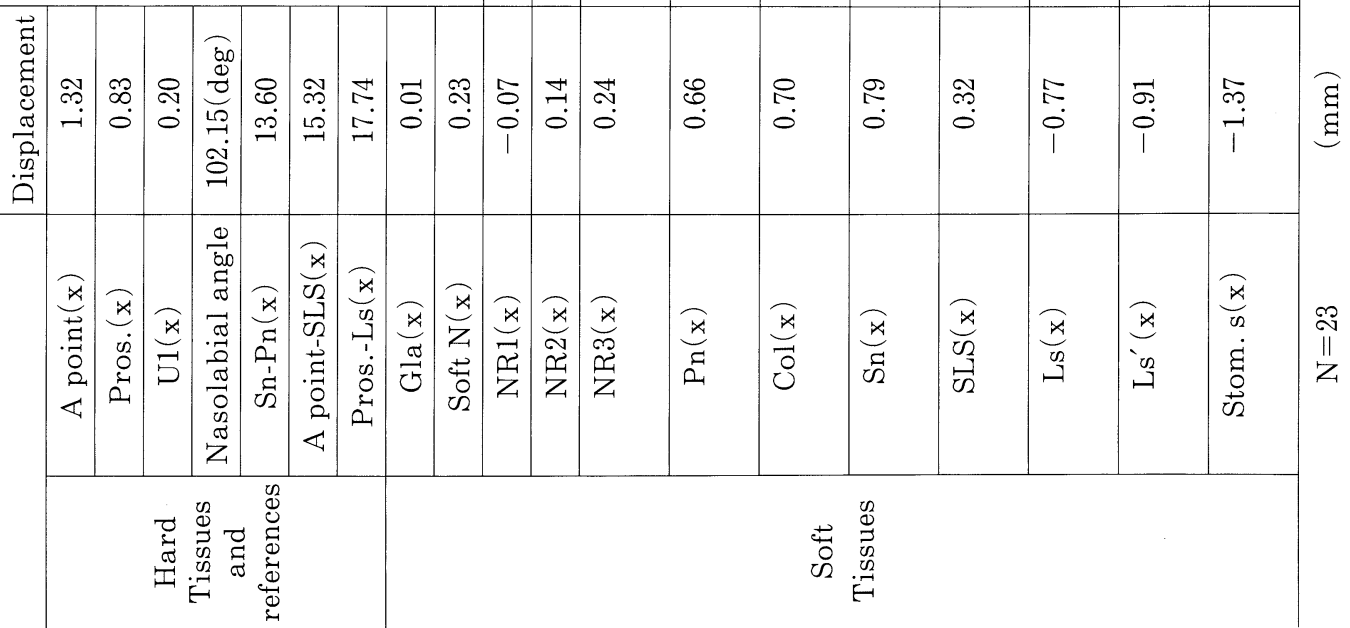




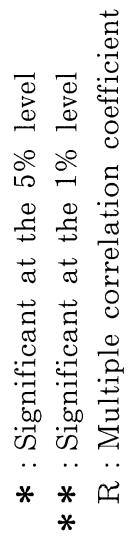

\begin{tabular}{|c|c|c|c|c|c|c|c|c|c|}
\hline & & * & & $\begin{array}{l}* \\
*\end{array}$ & $\begin{array}{l}* \\
*\end{array}$ & * & $*$ & $\begin{array}{l}* \\
*\end{array}$ & $\begin{array}{l}* \\
*\end{array}$ \\
\hline & $\begin{array}{l}\stackrel{0}{\Xi} \\
\stackrel{\sigma}{\nabla} \\
p\end{array}$ & $\underset{\leftrightarrow}{\sharp}$ & $\underset{+}{\stackrel{9}{+}}$ & 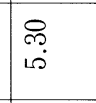 & $\begin{array}{l}8 \\
\underset{+}{-}\end{array}$ & $\begin{array}{l}\tilde{b} \\
+ \\
+\end{array}$ & $\underbrace{}_{i \infty}$ & $\begin{array}{l}\vec{\sigma} \\
\stackrel{9}{-} \\
-\end{array}$ & $\begin{array}{l}\mathscr{8} \\
\dot{\varphi} \\
-1\end{array}$ \\
\hline$\infty$ & & $\stackrel{\stackrel{1}{9}}{\stackrel{0}{0}}$ & $\stackrel{0}{\mathscr{H}}$ & $\begin{array}{l}\infty \\
\stackrel{0}{0} \\
0\end{array}$ & $\begin{array}{l}12 \\
\infty \\
0 \\
0\end{array}$ & $\begin{array}{l}8 \\
\ddot{8} \\
0\end{array}$ & م. & $\begin{array}{l}0 \\
\emptyset \\
0\end{array}$ & $\begin{array}{l}? \\
0\end{array}$ \\
\hline$\dot{0}$ & $\begin{array}{l}\overrightarrow{\vec{z}} \\
\vec{\sigma} \\
\frac{\pi}{2}\end{array}$ & $\stackrel{\text { मै }}{\circ}$ & $\stackrel{\text { I }}{\stackrel{\overbrace{}}{-}}$ & $\vec{\sigma}$ & ت্] & 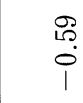 & $\begin{array}{l}\triangleright \\
\infty \\
\infty\end{array}$ & $\begin{array}{l}\mathbb{N} \\
\tilde{\leftrightarrow} \\
0 \\
1\end{array}$ & $\stackrel{0}{0}$ \\
\hline & 10 & & & & & & & & \\
\hline & $\nabla$ & & & & & & & & \\
\hline 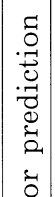 & $\infty$ & & & 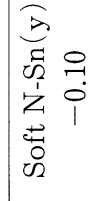 & 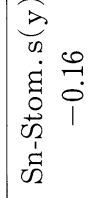 & $\begin{array}{ll}\vec{B} & \\
\dot{n} & \ddots \\
0 & 0 \\
0 & 0 \\
0 & \end{array}$ & & & \\
\hline 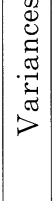 & $\infty$ & & & 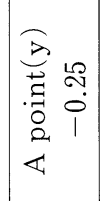 & 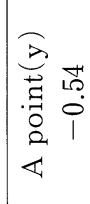 & 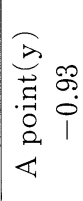 & 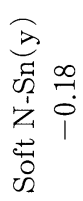 & & \\
\hline & $\neg$ & $\begin{array}{ll}\Xi & \infty \\
\vdots & 0 \\
5 & 0\end{array}$ & 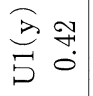 & $\begin{array}{cc}3 & -5 \\
5 & 0\end{array}$ & 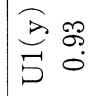 & $\begin{array}{l}3 \\
3 \\
5\end{array}$ & 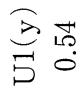 & $\begin{array}{ll}\vec{B} & \infty \\
\vdots & 0 \\
& 0\end{array}$ & 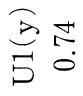 \\
\hline
\end{tabular}

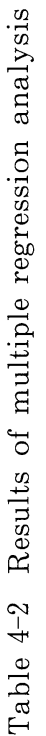

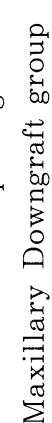

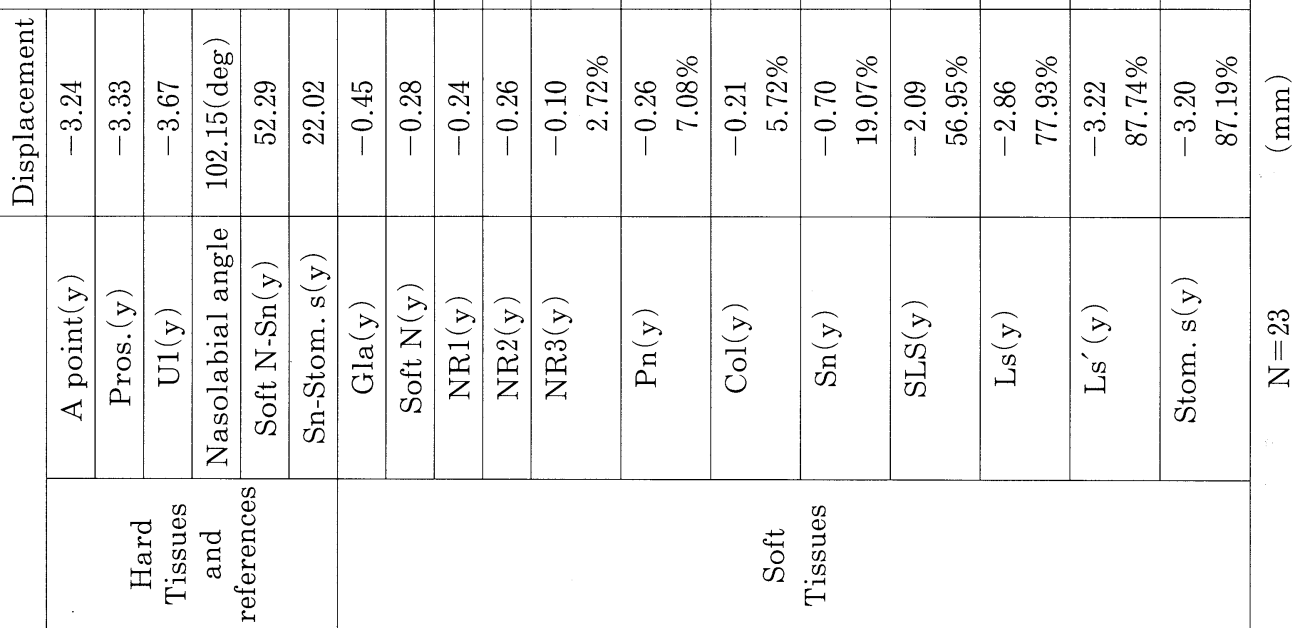

